DOI: $10.36695 / 2219-5521.2 .2020 .73$

удк 340.5

\title{
Ж.В. УДОВЕНКО
}

Жанна Володимирівна Удовенко, кандидат юридичних наук, дочент, доцент Національного університету «Києво-Могилянська академія»*

ORCID: 0000-0002-4100-0723

\section{АНАЛІЗ МІЖНАРОДНОГО ЗАКОНОДАВСТВА ЩОДО НЕВТРУЧАННЯ В ОСОБИСТЕ ТА СІМЕЙНЕ ЖИТТЯ}

Постановка проблеми. Питання невтручання в особисте та сімейне життя за кримінальним процесуальним законодавством України та зарубіжних країн малодосліджені та не систематизовані. Водночас проведення порівняльно-правових досліджень надає змогу вийти за межі національної правової системи, поглянути під особливим кутом зору на низку традиційних проблем юридичної науки та практики, розширити обрії юридичних пошуків, здійснити обмін правовою інформацією, науковими ідеями, враховувати як позитивний, так і негативний зарубіжний юридичний досвід у різних сферах - у науковій, освітянській і практичній ${ }^{1}$

Формулювання мети статті. Метою статті $\epsilon$ визначення спільних основних особливостей і відмінностей у законодавствах країн СС та України щодо дослідження міжнародного законодавства про унормування засади невтручання в особисте та сімейне життя під час здійснення кримінального провадження й дотримання прав та законних інтересів його учасників.

Виклад основного матеріалу дослідження. Законодавство про «прайвесі» бере свої витоки з 1361 р., коли англійськими суддями був прийнятий Мирний акт (Peace Act), що став юридичною основою для арешту наглядачів. У 1765 р. британський лорд Кемден, критикуючи намагання виправдати вторгнення в житло і вилучення паперів, писав про твердження, що в його країні немає закону, який дозволяє виправдати винуватця, а якби такий закон існував, він би підірвав спокій в суспільстві, оскільки папери - іноді найцінніше, що є у людини.

За образним висловом члена англійського парламенту Вільяма Пітта всі королівські сили не владні над жебраком, якщо він знаходиться в своїй халупі. Вона може бути старою, іï дах може труситися, вітер може продувати їі наскрізь, грози й зливи можуть проникати всередину, але ні король Англії, ні всі його сили не сміють переступити поріг цього напівзруйнованого житла. Звичайно, подібні питання привертали увагу не лише британської юстиції. У 1776 р. парламент Швеції видав акт під назвою «Доступ до громадських архівів». Відповідно до цього документа, держава мала право використовувати будь-яку зібрану нею інформацію лише в законних цілях. У Франції в 1858 р. ввели великий грошовий штраф за публікацію приватних даних ${ }^{2}$.

Водночас систематичне дослідження «прайвесі» веде свою історію саме з роботи С. Уоррена і Л. Брендіса «Право на приватне життя» (The Right To Privacy) 3 , присвяченої неприпустимості втручання преси в певні сторони приватного життя людини. Як цілком слушно зазначає О.В. Ходус, «надане ними юридичне визначення приватності (у значенні «права бути залишеним наодинці»), розглядали принцип «недоторканності особистого» (конфіденційності особистої інформації) як неодмінну умову «права бути особою». До сказаного слід додати, що «рrivacy» - типове англійське поняття, що створює додаткові труднощі 3 його інтерпретацією. Зокрема, якщо в англосаксонській мовній традиції «рrivacy» широко вживають не лише в юриспруденції або дизайні, а й у буденній мові, то іiі присутність, приміром, в українському мовному просторі, вже не так очевидна, хоча й можна виявити певну співзвучність між англійським «рrivacy» і українськими лексемами «приватне життя», «приватна власність», «приватні стосунки» ${ }^{4}$. Незважаючи на те, що в судовій практиці це право існує вже кілька десятиліть, ні Конституція США, ні Конституції більшості європейських країн не згадують про таке право, як невтручання в приватне життя. Проте законодавство, що передбачає окремі гарантії захисту приватного життя, все ж таки існує. Для прикладу, в США персональну інформацію розглядають відповідно до концепції «рrivacy». Цю концепцію реалізують через Cтандарт CSA, прийнятий у 1996 р. Вказаний нормативно-правовий документ використовують в Америці головним чином тому, що його поширюють на всі країни-члени НАТО.

У минулому, на думку Р. Стандлера, проблема «прайвесі» не була такою актуальною. Зберегти в таємниці, зокрема, зміст розмови можна було, зробивши елементарні заходи запобігання. Науково-технічний прогрес запровадив нові інформаційні технології, що надають фактично безмежні можливості збирання, аналізу та поширення інформації про приватних осіб. Самостійно захистити себе стало практично неможливо, і виникла необхідність в державному (законодавчому) регулюванні 5 .

Г.Б. Романовський справедливо вбачає причини цього явища не лише в «ранньому віці» права на невтручання в приватне життя, а й у тому, що «воно багатьма юристами визнається як нематеріальне благо, яке не можна виокремити, захистити, «помацати». 3 недоторканністю житла і таємним листуванням таких проблем не виникає. Житло - це об'єкт, який не можна заховати в кишені, як і таємницю листування, що безпосередньо пов'язане $з$ реальними предметами - листами, телеграмами тощо» 6 . На наш погляд, право на

(C) Ж.В. Удовенко, 2020

* Zhanna Udovenko, Ph.D. in Law, Associate Professor, Associate Professor of the National University of «Kyiv-Mohyla Academy» 
невтручання у приватне життя, незважаючи на свою нематеріальність, є первинним, а таємницю листування і недоторканність житла можна розглядати не лише як самостійні права особи, а й як найважливіші гарантії права на приватне життя.

Проте більшість Конституцій країн Свропейського Союзу не містять спеціальних норм щодо невтручання у приватне життя громадян. До таких держав належать Австрія, Німеччина, Данія, Ірландія, Італія, Люксембург, Фінляндія, Франція. Водночас у законодавстві цих країн, як правило, передбачено низку засобів захисту особистого життя: недоторканність житла та таємницю листування, телефонних розмов, телеграфних та інших повідомлень. Зазвичай зазначені й підстави обмеження цих прав.

Для прикладу, у ст. 10 Основного закону Австрії встановлено, що таємниця листування не може бути порушеною. Вилучення кореспонденції, за винятком передбачених законом випадків арешту та обшуку, може проводитися лише в умовах війни чи на підставі судового наказу відповідно до діючих законів․

У ст. ст. 13-15 Конституції Італійської Республіки 1947 р. вказано, що недоторканність житла і таємниця листування можуть бути обмежені у випадках і в порядку, встановленому законом і відповідно до гарантій, встановлених для охорони особистої свободи ${ }^{8}$. Відповідно до ст. 13 Основного закону Німеччини 1949 р., проведення обшуків можливе лише за розпорядженням судді, а у випадках, коли є небезпека зволікання, також за розпорядженням інших, передбачених законом, органів у встановленому законом порядку. У свою чергу, ст. 10 цього Закону передбачає, що таємниця листування, а також поштового, телеграфного та телефонного зв'язку, є недоторканними. Обмеження можуть бути встановлені лише на підставі закону9.

Конституції Бельгії, Греції, Іспанії, Португалії, Швеції, поряд із правами на недоторканність житла і таємницю листування, поштових та інших повідомлень, містять спеціальні норми, присвячені захисту приватного життя, особистої й сімейної таємниці. Для прикладу, в Конституції Швеції 1974 р. передбачено «святість приватного життя». 3 метою іiі охорони можливе обмеження свободи, вираження поглядів та свободи інформації. У 1988 р. Основний закон цієї країни був доповнений забороною вносити персональні дані у «загальний реєстр» без згоди громадянина. Якщо законом не передбачено інше, іноземець має також захист від особистого та домашнього обшуку, а також від втручання в інтимні відносини ${ }^{10}$. Докладно регламентовано процедуру недоторканності приватного життя у ст. 10 Конституції Королівства Нідерландів 1983 р. У ст. 12 Конституції цієї держави закріплено норму про те, що особи, які хочуть проникнути до житлового приміщення на законних підставах, мають пред’явити документи, що засвідчують особу, і пояснити причини своєї вимоги. Особам, які проживають у цьому приміщенні, надається письмовий звіт ${ }^{11}$. Натомість детальний порядок захисту права на невтручання в приватне життя під час збирання та розповсюдження інформації встановлений спеціальним Актом парламенту.

Деяка схожість формулювань в конституціях різних країн багато в чому пов'язана з тим, що з другої половини XX ст. на їх внутрішньодержавне право стало впливати міжнародно-правове регулювання аналізованих правовідносин у сфері захисту прав і свобод людини. Це знаходить свій прояв у тому, що держави, підписуючи конкретний міжнародний договір, мають визначити його несуперечність національному законодавству або, за необхідності, зобов'язані привести своє внутрішнє законодавство у відповідність до міжнародних стандартів. У цих випадках мають бути створені національні засоби правового захисту, ідентичні міжнародним.

Нині захист прав і основних свобод людини на внутрішньому і міжнародному рівні тісно пов'язані між собою. Більш того, міжнародні механізми підсилюють дію внутрішнього захисту прав людини.

Слід зазначити, що принцип невтручання в особисте і сімейне життя не закріплений не лише у Конституціях низки європейських держав, а й у їх кримінально-процесуальному законодавстві, зокрема у Німеччині, Італії, Іспанії, Австрії, Франції.

Визначаючи держави для проведення компаративістського дослідження кримінального процесуального законодавства СС щодо невтручання в приватне життя, ми вирішили відійти від традиційних підходів та застосувати класифікацію, яку вперше запропонувала С.Я. Лихова 12 і яка $є$ найбільш актуальною і оптимально відповідає вимогам сучасного стану компаративного дослідження. Безумовно, можна погодитися 3 тим, що хоча Україна є державою, право якої умовно можна віднести до романо-германської правової сім'ї, великого значення набуває не стільки романо-германська традиція, скільки правові акти тих міжнародних організацій, учасницею яких є або прагне бути Україна (РС, СНД, Світова Організація Торгівлі, НАТО, СС та інші) ${ }^{13}$. Саме така методика дасть змогу, по-перше, проаналізувати особливості законодавства окремих держав-учасниць СС; подруге, встановити відповідність національного законодавства європейським нормам і стандартам; по-третє, дійти висновків щодо можливості і необхідності реформування вітчизняного законодавства 3 метою його адаптації до законодавства країн ЄС в умовах глобалізації та євроінтеграції. Тож дослідження законодавства цих країн сприятиме визначенню змісту та сутності правових традицій, які прагне гармонізувати Україна.

Для прикладу, у Кримінально-процесуальному кодексі ФРН (КПК ФРН) система принципів кримінального провадження взагалі не визначена ${ }^{14}$. Серед науковців також не існує єдиного підходу до цього питання. Зокрема, М.Г. Стойко стверджує, що фундаментальними принципами німецького кримінального процесу є: принцип обвинувачення, офіційності, обов’язок кримінального переслідування, розслідування, усності, безпосередності, гласності, вільної оцінки доказів і «швидкого» суду15. Натомість А.В. Молдован уточнює, що з усіх принципів у КПК ФРН прямо закріплено лише принципи офіційності (ч. $1 \S 152$ ), обвинувачення $(\S 151,155,264)$, законності (ч. 2 § 152), обов’язку дослідження всіх обставин кримінальної справи (ч. 2 $\S 155,244)^{16}$. Водночас, на думку Уве Хелльмана, яку наводять П. Головненков та Н. Спица, принципами кримінального процесу ФРН є: 1) законність; 2) монополія держави на кримінальне переслідування; 3) офіційне розслідування; 4) усність і публічність; 5) вільна оцінка доказів; 6) недоторканність людської гідності; 7) гарантії, передбачені ст. 6 Конвенції про захист прав людини і основоположних свобод ${ }^{17}$. Отже, німецький законодавець не вказує переліку засад кримінально-процесуальної діяльності. Натомість у КПК України 
2012 р. основоположні засади кримінального провадження визначені в окремому розділі із застереженням, що зміст і форма кримінального провадження повинні відповідати його загальним засадам.

Що стосується держав пострадянського простору, то засада невтручання в приватне життя знайшла своє диференційоване відображення в низці норм КПК. Для прикладу, у ч. 1 ст. 15 КПК Молдови визначено, що будь-яка особа користується правом недоторканності приватного життя, таємниці інтимного і сімейного життя, захисту честі й гідності особистості. Під час кримінального судочинства ніхто не має права самоправно і незаконно втручатися в інтимне життя людини.

Під час процесуальних дій, зазначено у ч. 2 вказаного Кодексу, не повинні збиратися без потреби відомості про приватне і інтимне життя особи, які особа вважає конфіденційними. Учасники процесуальних дій на вимогу органу кримінального переслідування і судової інстанції беруть на себе письмове зобов'язання про нерозголошення даних такого роду 18.

У ч. 1 ст. 13 КПК Республіки Білорусь передбачено охорону особистого життя в наступній редакції: «Кожен має право на захист від незаконного втручання в його особисте життя, у тому числі від посягання на таємницю його кореспонденції, телефонних та інших повідомлень. Ніхто не може при провадженні за матеріалами в кримінальній справі бути позбавлений зазначеного права або обмежений у ньому інакше як 3 підстав і в порядку, встановлених цим Кодексом» 19.

Водночас залишаються дискусійними питання щодо відсутність чіткої методології визначення змісту та обсягу поняття «приватне життя»; не конкретизовано й не окреслено його зміст.

Варто зазначити, що нечітке формулювання приватності в законодавстві та юридичній літературі призвело до вживання різних термінів для позначення відповідного поняття: «приватне життя», «особисте життя», «сімейне життя», «недоторканність приватного життя».

Проведений аналіз норм законодавства різних країн допомагає визначити прогалини в національному законодавстві з проблем врегулювання невтручання в особисте і сімейне життя, усунути їх шляхом внесення змін та доповнень до Конституції України, КПК України та Законів України з метою удосконалення процесуальних аспектів, що гарантують невтручання в приватне життя громадян, які беруть участь у кримінальному провадженні.

Саме під час порівняльно-правового аналізу є можливість виділити найкращі та прогресивні здобутки зарубіжної кримінально-процесуальної науки з метою їх імплементації у законодавство України.

Висновки. Отже, приватне життя - особлива сфера відносин, що не підлягає зовнішньому контролю і знаходиться за межами права. Проте саме право покликане гарантувати невтручання в приватне життя. Особливої актуальності це положення набуває під час здійснення кримінального провадження, коли існує занадто великий ризик порушення прав та законних інтересів його учасників. Обмеження цих прав можливе лише в порядку, передбаченому законодавством, та виключно для досягнення завдань кримінального провадження з метою захисту держави, суспільства та окремих громадян від злочинних посягань.

1 Ткаченко В.Д., Погребняк С.П. Лук’янов Д.В Порівняльне правознавство: підручник для студентів юридичних спеціальностей вищих навчальних закладів. Харків: Право, 2003. 274 с.

2 Banisar D. Freedom of Informaition around the World. 2006, Privacy International. P. 16.

3 Лузин В.В. Право на смерть. Сибирский юридический вестник. 1998. № 3. С. 14-15.

${ }^{4}$ Ходус О.В. Феномен приватності: соціально-філософська рефлексія : дис. ... канд. філ. наук: 09.00 .03 / Дніпр. нац. унів. ім. Олеся Гончара. Дніпро, 2018. 530 с.

5 Standler R.B. Privacy Law in the USA. URL: www://rbs2 com/privacy htm (Last accessed: 14.05.2020).

6 Романовский Г.Б. Нормативное закрепление права на неприкосновенность частной жизни. Юрист. 2000. № 11. С. 3-5.

${ }^{7}$ Конституція Австрії. URL: https://legalns.com/компетентные-юристы/правовая-библиотека/конституции-стран-мира (дата звернення: 13.05.2020).

8 Конституція Італійської Республіки (з передмовою Володимира Шаповала). Київ: Москаленко О.М., 2018. 62 с.

${ }_{9}^{9}$ Конституція Федеральної Республіки Німечини. URL: https://www.1000dokumente.de/?cdokument_de\&dokument=0014_ gru\&l=ru\&object=translation (дата звернення: 13.05.2020).

${ }^{10}$ Конституція Швеції URL: https://legalns.com/компетентные-юристы/правовая-библиотека/конституции-стран-мира (дата звернення: 13.05.2020).

11 Конституція Королівства Нідерландів. URL: https://legalns.com/компетентные-юристы/правовая-библиотека/конститу ции-стран-мира (дата звернення: 13.05.2020).

12 Андрушко П.П., Зінченко І.О., Лихова С.Я. Кримінальна відповідальність за порушення виборчих і референдних прав / за заг. ред. В.П. Тихого. Харків: Кроссроуд, 2008. 344 с.

13 Лиськов М.О. Кримінально-правова характеристика складів злочинів проти трудових прав людини: дис. ... канд. юрид. наук: 12.00.08. Львів: Львівський держ. ун-т внутрішніх справ, 2012. 208 с.

14 Уголовно-процессуальный кодекс ФРГ. URL: https://pravo.org.ua/files/_(1).pdf?_cf_chl_jschl_t__ (дата звернення: 13.05.2020).

15 Стойко Н.Г. Уголовный процесс западных государств і России: сравнительное теоретико-правовое исследование англо-американской и романо-германской правовых систем: монография. Санкт-Петербург: Издательский Дом Санкт-Петербургского государственного университета, 2006. С. 264.

16 Молдован А.В. Кримінальний процес: Україна, ФРН, Франція, Англія, США: навч. посіб. Київ: Центр навчальної літератури, 2005. $352 \mathrm{c}$.

${ }^{17}$ Головненков П., Спица Н. Уголовно-процессуальный кодекс Федеративной Республики Германия - Strafprozessordnung (StPO): научно-практический комментарий и перевод текста закона со вступительной статьей профессора Уве Хелльманна «Введение в уголовно-процессуальное право ФРГ» Potsdam: Umversitztsverlag Potsdam. 2012. 405 с.

18 KПК Молдовы. URL: http://pravo.org.ua/files/_.pdf (дата звернення: 15.05.2020).

${ }^{19}$ KПК Республики Беларусь. URL: https://etalonline.by/document/?regnum=HK9900295 (дата звернення: 15.05.2020). 
Резюме

Удовенко Ж.В. Аналіз міжнародного законодавства щодо невтручання в особисте та сімейне життя.

У статті проаналізовані базові принципи, міжнародні правові акти, зокрема Конституції США та країн Свросоюзу, що регламентують відносини у сфері особистого та сімейного життя. У дослідженні визначено особливості національних регулятивних підходів невтручання в приватне життя, які мають розвинене законодавство і багаторічний досвід з питань захисту прав і свобод людини. Узагальнено міжнародний досвід провідних країн світу у сфері захисту особистого та сімейного життя. У зв'язку з тим, що поняття «невтручання в приватне життя» $є$ відносно новим для вітчизняного законодавства України, значний інтерес викликає вивчення зарубіжного досвіду правового регулювання цієї засади кримінального провадження.

Ключові слова: засади кримінального провадження, принципи законодавства, приватне життя, особисте життя, сімейне життя, захист, людина.

\section{Резюме}

Удовенко Ж.В. Анализ международного законодательства невмешательства в личную и семейную жизнь.

В статье проанализированы базовые принципы, международные правовые акты, в частности Конституции США и стран Евросоюза, регламентирующие отношения в сфере личной и семейной жизни. В исследовании определены особенности национальных регулятивных подходов невмешательства в частную жизнь, которые имеют развитое законодательство и многолетний опыт по вопросам защиты прав и свобод человека. Обобщен международный опыт ведущих стран мира в сфере защиты личной и семейной жизни. В связи с тем, что понятие «невмешательство в частную жизнь» является относительно новым для отечественного законодательства Украины, значительный интерес представляет изучение зарубежного опыта правового регулирования этого принципа уголовного производства.

Ключевые слова: принципы уголовного производства, принципы законодательства, частная жизнь, личная жизнь, семейная жизнь, защита, человек.

\section{Summary}

Zhanna Udovenko. Analysis of international legislation on non-interference in personal and family life.

Abstract. This article analyzes the basic principles of international legal acts, the Constitution of the USA and the countries of the European Union, regulating relations in the sphere of protection personal and family life. Due to the fact that the concept of "noninterference into privacy" is relatively new to the criminal procedural legislation of Ukraine, the basics for normative legal regulation of a justified interference with privacy by state authorities while conducting criminal investigations are emphasized; their importance for criminal investigation is paid special attention in judicial consideration along with taking into account the specifics of national legislation. The purpose of the article is to investigate the concept of the right to non-interference within the privacy.

The study determined the peculiarities of national regulatory approaches to non-interference with private life that have developed legislation and years of experience in protecting human rights and freedoms. This paper summarizes the international experience of leading countries in the field of protection of personal and family life is generalized. Since the concept of "non-interference with private life" is relatively new to the domestic legislation of Ukraine, it is of great interest to study foreign experience of legal regulation of this basis of criminal proceedings. The specificity of the purpose and objectives of the study necessitated the use of dialectical, comparative-legal, historical-legal, formal-logical, system-structural, sociological, and statistical and other methods of scientific search.

As a result of the research, on the basis of the analysis of international legal documents, the Constitution of Ukraine, the Criminal Procedure Code of Ukraine and the positions covered in scientific publications, special attention is paid to the urgency on observing the guarantees of non-interference with privacy in criminal proceedings, when there is a high risk of violation of rights and legitimate interests of its participants. It is argued that restrictions on these rights are possible only in the manner guaranteed by the law and solely to achieve the objectives of criminal proceedings in order to protect the state, society and individual citizens from criminal encroachments.

Key words: principles of criminal proceedings, principles of law, private life, personal life, family life, protection, people.

DOI: $10.36695 / 2219-5521.2 .2020 .74$

УДК 343.341

\section{T.0. ЧACOBA}

Тетяна Олександрівна Часова, кандидат юридичних наук, старший викладач Академії праці, соціальних відносин та туризму, адвокат*

ORCID: 0000-0002-0293-6123

\section{ВИКОРИСТАННЯ ФІНАНСОВОГО МОНІТОРИНГУ ПІД ЧАС РОЗСЛІДУВАННЯ ЗЛОЧИНІВ У СФЕРІ ЕКОНОМІКИ}

Постановка проблеми. Забезпечення економічної безпеки держави та недопущення вчинення злочинів у сфері економіки можливо за умови боротьби з легалізацією (відмиванням) доходів, отриманих злочинним шляхом. Вчинення економічних злочинів підриває економічну та фінансову систему держави, посягає на законні інтереси як учасників бізнесу, так і його окремих елементів. Найчастіше «відмиті» грошові кошти, отримані злочинним шляхом, у подальшому застосовуються в підприємницькій діяльності з метою отриман-

(C) Т.О. Часова, 2020

* Tetiana Chasova, Ph.D. in Law, Senior Lecturer of the Academy of Labor, Social Relations and Tourism 